\title{
BANK ACTIVITIES AND THEIR RISK. DOES AN OPTIMAL MODEL EXIST IN BANKING?
}

Why did the German and Swiss banks suffer severely from the mortgage crisis while the banks following the "originate-and-distribute" model were less affected by the mortgage crisis? Why were the Spanish banks hardly affected by the financial distress and banks from Central and Eastern Europe were not impacted at all? How profitable were all these institutions and what was their risk? The mortgage crisis has revealed that the general knowledge regarding the banks activities and their risk is notably limited. In addition, the recent literature provides ambiguous results on the impact of bank strategies on bank risk. By analyzing the most prevalent banking strategies observed before the mortgage crisis among 360 banks around the world, we demonstrate the presence of a wide heterogeneity in the banking strategies. These can be grouped into the originator, trader, neutral and traditional models. We also analyze how the specific banking strategies affect bank distress during the mortgage crisis. We determine that the riskiest banking model is for cases in which the banks specialize in trading and securitization. Yet, the least risky banks seem to be the banks engaged in traditional banking activities. However, our evidence suggests that a welldiversified, neutral model, allows banks to stay profitable without a significant risk increase effect.

Keywords: bank risk, business models, bank regulation, financial crisis, banking stability

DOI: $10.15611 /$ aoe.2016.1.06

\section{INTRODUCTION}

The mortgage crisis has revealed that the general knowledge about the activity undertaken by banks is notably limited. Economists and researchers started to note that supervisory authorities did not have reliable knowledge about the banks investments before the mortgage crisis. This prohibited regulators from properly assessing the risk in the banking sector (Lo, 2009; McCarthy et al., 2010). In addition, many transactions undertaken by banks before the mortgage crisis were of such a complex nature that it was difficult to understand their structure and thus the associated risk. Moreover the banks were so closely linked that the contagion effects quickly spread across the globe. In the end many governments were forced to rescue the troubled institutions when their assets declined in value, and the level of capital was

\footnotetext{
* Department of Accounting, Kozminski University, Warsaw
} 
quickly deteriorating. Though several years have passed, there is still an open debate regarding how to regulate the banking sectors to limit risky investments in the future. Thus this paper offers an important contribution to the literature on the determinants of financial crises, bank behaviour, and the shape of future banking regulations. We conclude with the implications for the regulators.

In theory we can distinguish between three banking models based on the structure of the bank's assets and liabilities. These banking models are: commercial, investment and universal. The commercial banks represent the traditional model of banking business, as these institutions receive deposits and convert them into loans. The investment banks are involved with capital market investments and products. Finally, the universal banks represent the model that boosts bank performance by diversifying the lending activities through capital market involvement. According to the theoretical literature, the specific asset-liability structure justifies the nature of the banking business and thus makes these models less vulnerable to financial turbulence. Moreover, the dominance of each model under a specific country's institutional infrastructure (e.g. the investment banking model mostly dominates in countries with capital-based economies, and the universal model tends to dominate in banking-based economies) allows for the efficient functioning of domestic financial systems (Schmidt and Tyrell, 2004).

In reality, we could observe that banks started to exhibit a mix of features characterized by various banking models. Let us take the example of UBS and Deutsche Bank, whose assets mainly consisted of trading activities, whereas the liability exhibited the traditional nature of its business. Moreover, heterogeneity between the same banking models has increased recently. This has been particularly observable within the universal model. While such banks as Bank of America and HSBC earned significant profits from securitization transactions, other banks such as UBS, ING and Deutsche Bank made most of their earnings from trading activities. As a result, banking based on the commercial, investment, and universal models has increased in complexity and heterogeneity leading to the emergence of new models - much more complex and diverse than those discussed in the literature thus far. In fact we know very little about these new banking business models and their primary characteristics.

Empirically, the studies do not provide clear results about the riskiness of new banking models. The existing studies mostly concentrate on the link between a bank's individual features and its risk. More specifically, Allen and Jagtiani (2000) document that bank risk increases when banks expand 
their business to securities and insurance activities. Both income sources increase bank's systemic and individual risks. Other researchers claim that trading destabilizes banking business the most. Shleifer and Vishny (2010) and Diamond and Rajan (2010) document that expanding a bank balance sheet to trading is profitable in good times, however those banks suffer more than non-trading banks during bad times. Yet, Song and Thakor (2007), Wagner (2007) and Brunnermeier et al. (2012) claim that non-interest activities affect only systemic risk and allow banks to diversify away individual risk. Brunnermeier et al. (2012) show that trading, investment banking and venture capital income contribute significantly to the risk effect, and the two latter income sources contribute the most. Davis and Karim (2008) document that securitization and off-balance sheet activities add significantly to the bank's risk effect. In addition, economies of scale and scope characterize the predominant universal banking business model, causing banks to growth in size and complexity increasing the global systemic risk (Brunnermeier et al., 2012). Other studies point towards the stabilizing role of the universal banking business model, noting its diversification effects and its reduced exposure to individual and domestic systemic risk (Saunders and Walter, 1994, 2012; Buch et al., 2013). In particular these studies find that securities, underwriting, securities brokerage, and asset securitization allow banks to diversify and thus limit their risk (Litan, 1985; Wall; 1987; Uzun and Webb, 2007; Jiangali and Pritsker, 2008). This stream of literature documents that various non-interest activities may provide substantial diversification effects for banks' entire business and thus should not be eliminated from the scope of commercial banks' activities (Boot and Ratnovski, 2015).

However these studies do not assess entire banking strategies but rather their individual features. Moreover, they explicitly assume that the effect of bank activities and risk are of a linear nature. In fact the link might be nonlinear. For example Boot and Ratnovski (2015) document that the low level of non-interest activities should not endanger banking sector stability, whereas other studies have proven that non-interest income is positively correlated with the bank risk level. Finally, there is the endogenous problem between banks' characteristics such as profitability, efficiency, capital level, activities and the risk level.

Our study is distinct from the existing ones in many respects. First, we analyze entire banking strategies in 26 countries. These strategies have been identified based on banks' mix of interest- and non-interest activities. Then we analyze how these strategies have translated into banks' individual features. In the final step of our analysis, we evaluate the effect of banks' 
strategies on banks' systemic risk. We believe that such an approach allows us to address three potential problems existing in the empirical studies: a) heterogeneity in banks' activities, b) the non-linear effect of banks' activities on its systemic risk, and c) endogeneity in financial variables.

To this end we used 360 banks from 26 countries between 1995 and 2009. Our sample includes all global banks as well as their subsidiaries in foreign countries, to capture the potential interlinkages between them. We then group banks according to their strategies based on the level of interestand non-interest income. This allows us to evaluate the financial features of banks representing individual banking models. For this purpose we used the probit regression on our sample banks between 1995 and 2006. In the final step, we investigate how individual banking strategies behaved during the mortgage crisis by estimating their effect on four systemic important measures between 2007 and 2009.

Our results are interesting. Analyzing the structure of bank activities, we were able to identify four banking strategies: "originators" - banks that specialized in securitization, "traders" - banks that were the main buyers of the securitized assets, "neutrals" - banks for which securitization and trading were important although to a large extent offset by the credit activity, and "traditioners" - banks that mainly focused on credit activity. We then classified banks into these strategies based on a mix of interest- and noninterest income and evaluate their financial characteristics. We find that in our sample period, banks following the traditional model were smaller in size, more cost efficient, less capitalized, and less risky than the investment model. Similarly, the neutral model was more cost efficient than the originator and trader model; however compared to the traditional banks, these banks were larger in size, more profitable and more capitalized. We also find that the neutral model, similarly as the traditional model, exhibits lower risk for the banking sector, while the trader model shows the highest. Thus the neutral model confirms that banks might benefit from non-interest activities without a significant risk increase. The results suggest that this may happen only to the extent that the banks remain diversified. Once the non-interest activities start to dominate, the entire model is more exposed to systemic risk, and thus becomes risky. Consequently we find that though the trader and originator models had proven to be profitable and better capitalized before the mortgage crisis, they collapsed during the mortgage crisis of 2007-2009, causing these institutions to be severely distressed. The results suggest that the investment model is the riskiest only once the banks exceed a certain threshold, i.e. the investment activities start to dominate banking operations. 
Though our results are convincing and robust toward several specifications, we would like to add a comment on our approach used to identify the banking business models. We are aware that the link between banking strategy and its financial features might be of an endogenous nature. However, because our primary interest lies in the examination of the financial features of banks following individual banking models as well as an analysis of the differences existing between them, we argue that the endogeneity is of lesser concern for our analysis. Moreover, the income approach is just one of the styles showing how such a grouping can be made. The others could include funding strategies, capital structure, asset structure, off-balance sheet activities or a mix of them. However, since we aim at analyzing how bank activity determines its funding structure as well as bank performance, we decided to treat all financial variables exogenously. Nevertheless, we are aware of an identification problem with our grouping approach, which might limit the generalization of the results.

The paper is organized as follows. The second section analyzes the theoretical and empirical literature on the banking business models; the third section analyzes the sample; the fourth section discusses the methodology; the fifth and sixth section analyze the regression results, and finally the seventh section concludes.

\section{LITERATURE REVIEW}

\subsection{Banking models in theory}

The existing theoretical literature classifies banks into three following categories: commercial, investment, and universal institutions, depending on the asset-liability structure.

The first group of banks relies on traditional banking activities such as collecting short-term deposits and transforming them into long-term loans. Thus the asset structure of these banks mainly consists of the granted loans, and the interest income is the main source of banking revenue. Funding the loans through the deposits also has an economic foundation. Because the deposits, for the most part of a retail nature, are unlikely to be withdrawn prematurely due to their public protection, they are held for their liquidity services (Song and Thakor, 2007). An additional reason why lending and deposit-taking services can be provided within the same banking firm is because both financial services entail the provision of liquidity to bank customers, which in turn improves the institution's own liquidity management (Kashyap et al., 2002). Relationship banking constitutes an 
important part of this banking business model, and it allowed these banks to experience considerable interest margins for a very long time (Allen and Santomero, 2001). In addition, relationship banking allows these banks to withstand financial shocks (Song and Thakor, 2007; Elsas and Krahnen, 1998). As a result, De Jonghe (2010) and Demirgüç-Kunt and Huizinga (2010) find that banks suffer less from financial distress when their business consists of the traditional activities instead of investment activities. In recent decades the innovations and competition from capital markets have reduced the interest margins (Allen and Santomero, 2001; Boot and Thakor, 2000). This trend has encouraged these banks to search for additional yields (Rajan, 2006).

In turn, investment banks focus mainly on the fee-income generating activities and non-deposit funding. Their activities include trading, brokerage and other investment banking activities. While the investment banks are prohibited from taking deposits, their main source of funding is the capital market. Repo and commercial papers were the most prevalent recently (Kalemli-Ozcan et al., 2012). We have also observed the decline of the maturity of these banks' borrowing sources. The Financial Crisis Inquiry Commission (2011) claims that the US investment banks use of repo borrowing increased by almost one trillion dollars between 2004 and 2007, of which an increasing segment consisted of overnight repos. However, Hördahl and King (2008) argue that "the (former) top US investment banks funded roughly half of their assets using repo markets, with additional exposure due to off-balance sheet financing of their customers" (p. 39). Wu et al. (2011) indicate that banks most active in the securitization market were often found to have a lower solvency risk and higher profitability levels, and they were better capitalized. Thus the investment banking model has been characterized by a high proportion of fee and trading income, increased leverage and higher profitability ratios (Demirgüç-Kunt and Huizinga, 2010).

The universal model allows banks to combine investment banking with commercial activities. The re-introduction of this model in the US was made possible by Gramm-Leach-Bliley Act in 1999; however in many other countries around the world this model had been popular before then. The economic reasoning behind the universal model is that banks gain information on their customers in the provision of one financial service that may prove useful in the provision of other financial services to the same customers. The combination of various types of activities, for instance, loan making with securities underwriting, may increase returns as well as diversify the risks and improve bank performance. Though the intuition 
behind this model is to diversify the funding source, the recent data indicate that these banks were heavily involved in the US interbank market (McGuire and Von Peter, 2009). DeYoung (1994) and Rogers (1998) indicate that large amounts of fee-based or non-traditional products and services improved the efficiency of these banks in the 1980s and 1990s. However, DeYoung and Roland (2001) demonstrate that non-interest income increases banks profitability and also earnings volatility. Similar results are found by Stiroh and Rumble (2006) who indicate that diversifying income in nontraditional activities improves bank performance. The extent to which a bank can profit from the diversification of various income activities depends on the co-movements of the risky income from these activities. A relatively low correlation among key financial businesses should explain the positive stability-effect of the firm's scope (Saunders and Walter, 1994, 2012; Baele et al., 2007).

\subsection{Empirical literature on bank risk}

While the theoretical literature addresses the entire structure of bank assets and liabilities, the empirical papers examine instead the bank determinants of financial distress. This literature indicates that the choice of the banks' asset holdings, methods of funding, sources of income, and the size have a significant effect on the level of risk and thus the extent to which a bank has been affected by the mortgage crisis.

Specifically, these studies classify banks according to their income source, asset structure, funding strategies, diversification and capitalization levels. Stiroh (2004), Stiroh and Rumble (2006), and Fraser et al. (2002) find that non-interest income is associated with more volatile bank returns. DeYoung and Torna (2013) find that fee-based activities are associated with earnings variability in addition to increased revenues. Interestingly, DeJonghe (2010) indicates that the shift to non-traditional banking activities, which generate commissions, trading and other non-interest income, increases bank tail betas and thus reduces banking system stability. The author indicates that interest income is less risky than all the other revenue streams. Other indicators of bank specialization in traditional intermediation, such as a higher interest margin or higher loans-to-assets ratio, indicate that traditional banking activities result in lower systemic banking risk. Similar results are found by Brunnermeier et al. (2012) who indicate that higher non-interest income (non-core activities such as investment banking, venture capital and trading activities) have a higher contribution to systemic risk than traditional banking (deposit taking and 
lending). Importantly, recent papers also demonstrate that the extent to which a non-interest income affects the bank risk depends on the correlation between various income sources as well as its share in the total activities of the bank. Generally, a relatively low correlation among key financial businesses should explain the positive stability effect of diversification (Saunders and Walter, 1994; Baele et al., 2007). However, Baele et al. (2007) pointed out that the risk-decrease effect only holds for idiosyncratic risk. The non-interest income tends to increase the systemic risk. On the other hand, Acharya et al. (2009) showed that institutions deriving noninterest income mainly through interest related activities contributed less to the interconnectedness of the system prior to the financial crisis of 2007. Consequently the majority of the studies indicate that investment income can be blamed for a large part of the increase in risk (Brunnermeier et al., 2012). However recent studies started to note that the extent to which the investment risk affects the bank risk position also depends on the level of trading (Boot and Ratnovski, 2015). According to Boot and Ratnovski (2015), a low level of trading should not adversely affect a bank's position.

An additional group of studies investigates the relationship between asset structure and banking fragility. Foos et al. (2010) analyze the impact of loan growth and business models on bank risk in $15 \mathrm{EU}$ countries. The results indicate that banks with high rates of loan growth are riskier than more conservative banks. According to Duffie and Gârleanu (2001), securitization itself improves bank liquidity and has a positive effect on their overall market value. However, if securitization is used for financing purposes this additional funding could fuel riskier lending. Moreover, Franke and Krahnen (2008) argue that asset securitization increases exposure to systematic risk when the originating banks retain the first-loss position of securitized assets and invest the rest in additional loan portfolios. Shleifer and Vishny (2010) indicate that investor sentiment makes profits and the balance sheets of banks involved in the securitization process volatile. The authors also point out that this risk increases with bank leverage. Similarly, Cifuentes et al. (2005) and Brunnermeier and Sannikov (2011) show that when the market structure is complete and banks keep similar assets on their balance sheet, the contagion effect driven by asset price changes increases, and consequently the systemic risk in a banking sector increases. Acharya and Hasan (2001) studied the effect of specialization versus diversification of assets on the return and risk of Italian banks for the period 1993-1999. Their results indicate that a diversification in bank assets does not produce superior performance and/or greater safety for banks. 
Studies analyzing the role of bank funding demonstrate that depositfunded banks were less affected by the mortgage crisis, exhibited better performance, and were less risky (Demirgüç-Kunt and Huizinga, 2010). This is because the retail deposits are typically insured by the government, and their withdrawals in most circumstances are usually predictable at the aggregate level and to a large extent linked to depositor liquidity needs (Song and Thakor, 2007; Ivashina and Scharfstein, 2010; Demirgüç-Kunt and Huizinga, 2010). On the contrary, the banks that relied on wholesale funding were more heavily hit by the mortgage crisis. This is because in a liquidity crisis the wholesale market immediately reacts to the bad signals for the market situation. This effect is related to the fact that providers of short-term funding have little incentive to monitor banks and instead may simply withdraw their funds at the first negative market signal regarding the financial health of the client bank, triggering immediate funding tensions (Huang and Ratnovski, 2011). Interestingly, recent evidence also indicates that when funding from financial markets becomes unavailable or very expensive, the market values more positively those institutions that are funded to a greater extent by customer deposits (Beltratti and Stulz, 2012; Demirgüç-Kunt and Huizinga (2010). However, Allen et al. (2014) show that the interbank market is an important source of shock transmission between countries.

Finally, Demirgüç-Kunt and Huizinga (2010) find that better capitalized banks experienced a smaller decline in their equity value during the mortgage crisis than those that were less capitalized.

\section{BANKING BUSINESS MODELS AND THEIR CHARACTERISTICS}

\subsection{Sample}

For the purpose of our analysis we collected data from 360 global banking institutions and their subsidiaries located in the following OECD countries: Australia, Austria, Belgium, Canada, Chile, the Czech Republic, Denmark, Germany, Greece, Hungary, Ireland, Israel, France, Ireland, Italy, Luxembourg, the Netherlands, Mexico, Poland, Portugal, Slovakia, Spain, Switzerland, the United Kingdom, the United States, and New Zealand. Our banking sample focuses on multinational financial institutions and their subsidiaries. We argue that this sample is very representative for our research question. First, banks with a large international presence will be more affected by global financial shocks. Second, foreign subsidiaries of 
multinational banks might be affected by a financial shock through the internal capital market, which leads to the shock transmission in these countries (Allen et al., 2014; Popov and Udell, 2012).

By analyzing the asset structure of the identified financial institutions, we observe significant differences between these institutions. More specifically, we are able to distinguish four major banking strategies among the analyzed banks: banks heavily involved in securitization transactions, those involved in trading, those involved in lending, and banks exhibiting a balanced asset structure with both trading and lending activities approximately equal.

To assign individual banks to their individual strategies, we use an income approach that is prevalent in the existing studies. Based on a mix of interest- and non-interest income a bank earns, we classify banks into: "traditioners", "neutrals", "originators", and "traders". More specifically, we classify banks as "traditioners" if interest income of a bank is above the mean, and another source of income is below the mean; "neutrals" if both interest- and non-interest income is close to the mean; "originators" if the interest- and non-interest income is above the mean, and "traders", if the non-interest income is above the mean, however the interest income is below the mean. Intuitively, we would classify as originators the banks with a high share of non-interest income, specifically from securitization transactions. However, we also observed that for a few of these banks, credit activity still constituted a significant part of its operations. For example, the share of credit activity in the assets of Citibank constituted approximately $60 \%$ over our sample period. Consequently we categorize banks as originators when both their interest- and non-interest income is higher than the mean.

In addition we present the robustness analysis where we document that the income approach which we use to classify banks into their specific banking models is in accordance with the asset structure the banks hold. Moreover we also ensure that our results are not impaired by any country's institutional features.

The bank-level data used for our analysis come from Bureau van Dijk. Since we are interested in the financial differences between banking individual strategies, we perform a grouping based on the income averages between 1995 and 2006. This allows us to eliminate the fluctuations between banks activities in different years as well as limit the effect of monetary policy on banking strategies. To evaluate the risk of individual banking strategies we used the years of the mortgage crisis of 2007-2009.

A detailed description of the variables with their sources is presented in the Appendix. 


\subsection{Heterogeneity between the banks around the world}

Gropp and Heider (2010) indicate significant heterogeneity in the level of bank capital between the banks in various countries, which is not explained by the capital requirements but rather by the specific features of the banks. Figure 1 presents the heterogeneity between the banks representing various models in terms of the risk-return profile.

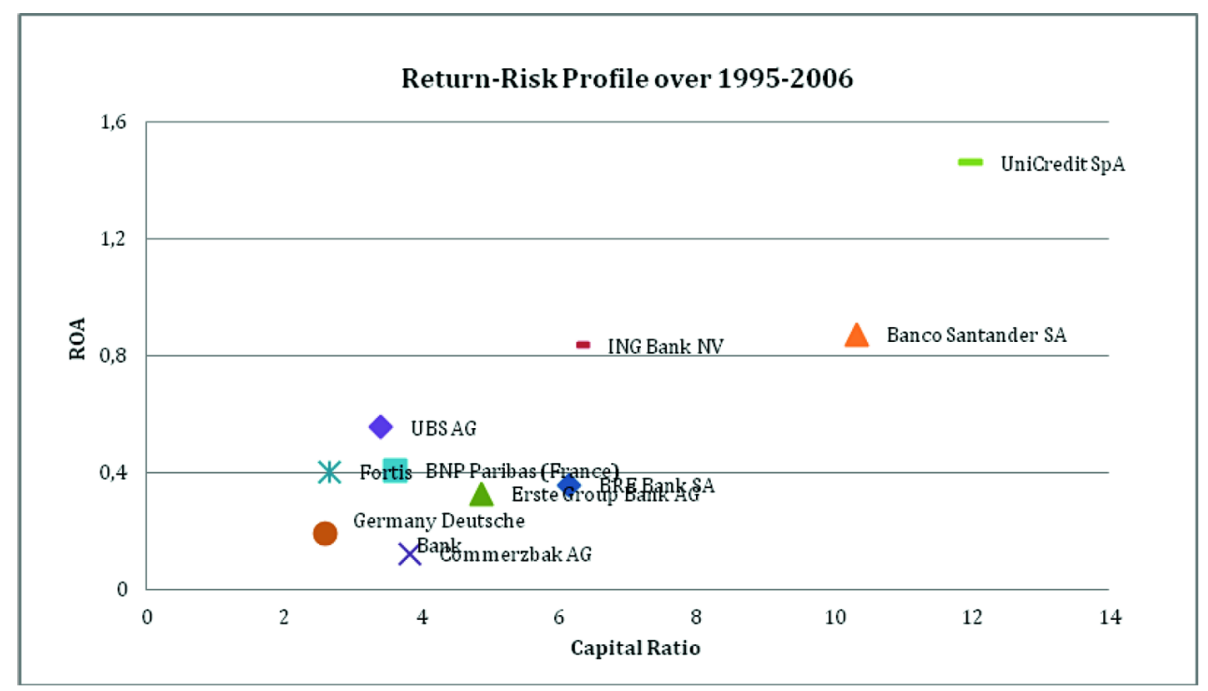

Figure 1. Heterogeneity between selected sample banks across countries based on averaged data $(\%)$

Source: Data from the Bankscope database

In general we find that banks with a similar nature of business fall close to each other on the graph. However, those with different businesses often diverge in their profiles significantly. For example, UniCredit and Banco Santander exhibited the highest profitability and capital ratio over the entire period of 1995-2006. This is interesting because these banks were neither heavily involved in securitization nor trading activities. However these banks exhibited very well-diversified asset structures, with an important share of activities in the emerging countries. On the other hand, we find that banks that were significantly involved in trading activities, such as UBS or Deutsche Bank, were not as profitable over the entire sample period, as has been suggested in some studies. In addition, the capital position of these 
banks was not highly favourable. In general, these banks had the lowest capital ratio among all the other banks over the entire period (except for ING). These results tend to suggest that, overall, non-interest activities are very risky and lead to increased performance volatility over a longer time period (Shleifer and Vishny, 2010).

\section{VARIABLES}

\subsection{Control variables}

Following the empirical literature, to identify the characteristics of specified banking models and to investigate the consequences for financial stability, we create four groups of regressors accounting for: bank capital, cost efficiency, profitability income and bank size. Consistent with the theoretical models, we argue that the banking business models vary with respect to these characteristics.

More specifically, we define bank capitalization as a ratio of equity to total assets. The literature indicates that the level of bank capitalization is an important determinant of financial distress during a crisis (Demirgüç-Kunt and Huizinga, 2010). Following these studies, banks that engaged in an excessive expansion of their activities will be more affected by the financial crisis than more conservative banks. Moreover, we expect that banks that cannot economize on their capital will have a lower capital ratio than banks that are more heavily involved in non-traditional banking activities. Thus, we expect that particularly the traditioners will exhibit a lower capital ratio than the other types of banks.

We included the asset structure measured as a proportion of loan activity in the bank's assets. Brunnermeier et al. (2012) indicate that investment activities, compared to traditional activities, to a larger extent expose banks to the systemic risk accompanying the financial crisis. Thus we expect that banks involved in investment activities are more affected by the financial crisis. In addition, DeJonghe (2010) shows that this especially applies to banks involved in trading activities. On the other hand, Foos et al. (2010) point out that if traditional banking is associated with excessive credit growth and international expansion, the banks are more exposed to systemic risk and more likely to experience distress during a financial crisis. Following this evidence, we argue that originators and traders will be the most affected by the financial distress, whereas traditioners and neutrals will be the least affected. 
We also include the profitability ratio measured by return on assets (ROA). We argue that banks activities linked more closely to the capital markets improve profitability due to higher margins, however they may also increase financial distress during the market downturn (Shleifer and Vishny, 2010). Following these studies, we argue that originators and traders will exhibit higher profitability ratios as well as higher risk. In addition, we control for the bank's efficiency measured by cost to income. The studies indicate that less efficient banks are more willing to take on additional risk and thus are more exposed to the distress risk during a market downturn (Kwan and Eisenbeis, 1997).

We also control for asset size. Following the existing literature demonstrating that larger banks are more willing to take on additional risk, we expect that originators, traders and neutrals will be more exposed to risk and thus more severely hit by a financial crisis compared to traditioners.

What is more, we also include the income sources into our analysis. Although the income variables reflect the nature of our banking business models, we decided to include them because the income source can be endogenously linked with other financial variables such as bank's cost efficiency, capital ratio, profitability and bank size. Therefore, to ensure the correctness of our empirical results, we include income interest to average assets as a control for the size of traditional banking activities and other operating income to average asset. We expect that originators and traders will be the most affected by the crisis due to their heavy involvement in trading and securitization, whereas neutrals and traditioners will be the least affected due to the limited participation in activities other than traditional banking activities. In addition, the Fitch analysts classify non-standard and "difficult to classify" income from banking activities as non-operating income, therefore we include the non-operating income to average assets. We notice that this variable takes a very high value especially for the originator model. Our intuition is that non-standard banking transactions, which might be related to the structure of securitization, were classified in the extraordinary items and thus inflate the non-operating income of these banks. Thus, we think that this item might indicate the "hidden" risk of this banking model.

Finally we also include country variables. We control for the banking sector concentration ratio measured as the ratio of the banking assets of the three largest institutions to the total banking sector assets, consistent with the hypothesis supported by the recent evidence that more concentrated banking sectors are less affected by the financial crisis due to the possibility of more careful monitoring of banks activities (Beck et al., 2006). 


\subsection{Measures of financial distress}

In the next step of our analysis, we aim at evaluating how various banking models affect the systemic risk of a country. To this end, we perform an analysis of the mortgage crisis years (2007-2009) using four alternative systemic risk measures.

First, we use financial support measures which indicate to what extent an institution received government support (bailout dummy) or has been nationalized (nationalization dummy). The construction of the first dummy is based on a collection of information relating to the public rescue of banks via capital injections, the issuance of state-guaranteed bonds, and other government-sponsored programs, whereas the nationalization dummy is limited to the takeover of a bank by the state. Hryckiewicz (2014) points out that nationalization is generally reserved for severely distressed banks. We use several sources for these variables, including the European Commission, central banks, the Bank for International Settlements, and Bloomberg. The resulting dependent dummy variables take the value of one if public financial support was received during the crisis and zero otherwise.

Second, we use a systemic importance dummy that indicates whether a bank is systemically important. The identification has been achieved based on the database of V-Lab, which has identified the systemically important institutions on a regular basis since 2000. The banks are defined as systemically important if they expect to experience a sharp capital shortfall once the banking sector downturn materializes. Acharya et al. (2010) indicate that firms with a high percentage of capital shortfall in a crisis are not only the biggest losers in a crisis but also are the firms that create or extend the crisis. Based on this information we create a dummy of one if a bank has been identified to be a systemically important during a mortgage crisis and zero if not.

Third, we also use a systemic risk measure, again created by the V-Lab. The systemic risk measure indicates the percentage of financial sector capital shortfall that would be experienced by this firm in the event of a crisis. In our opinion, this is a good measure of the financial distress of a bank.

\subsection{Summary statistics}

This subsection presents the summary statistics for the main variables used in our analysis. 
Table 1

Summary statistics

The data represent the summary statistics for the sample period between 1995 and 2006 grouped by the banking models of originators, traders, neutrals and traditioners. Classification is based upon the mean of various income sources: traditioners if the interest income is above the mean, and non-interest income is below the mean; neutrals if the interest- and non-interest incomes are close to the mean; originators if the interest- and noninterest incomes are above the mean; and traders if the non-interest income is above the mean, and the interest income is below the mean for the types of activities exhibited by the major banks in a country.

\begin{tabular}{|c|c|c|c|c|c|}
\hline & No. of obs. & Mean & Std. dev. & Min. & Max. \\
\hline \multicolumn{6}{|l|}{ TRADITIONERS } \\
\hline Log assets & 997 & 7.489 & 3.092 & -2.198 & 13.334 \\
\hline Interest income & 975 & 2.867 & 3.078 & -3.320 & 59.090 \\
\hline Operating non-interest income & 973 & 1.026 & 1.771 & -40.910 & 10.210 \\
\hline Fee and commission income & 353 & 1.177 & 2.006 & -3.282 & 14.188 \\
\hline Trading income & 289 & 0.152 & 0.517 & -3.050 & 2.766 \\
\hline Non-operating income & 821 & -0.316 & 1.686 & -36.120 & 16.930 \\
\hline Cost to income & 969 & 62.851 & 42.443 & 0.870 & 790.000 \\
\hline Capital ratio & 996 & 10.173 & 11.613 & -55.560 & 97.270 \\
\hline $\mathrm{ROA}$ & 997 & 0.702 & 2.238 & -33.340 & 25.520 \\
\hline Credit activity & 984 & 52.923 & 22.986 & 0.000 & 99.500 \\
\hline Bank asset concentration & 863 & 61.938 & 21.714 & 20.668 & 100.000 \\
\hline \multicolumn{6}{|l|}{ NEUTRALS } \\
\hline Log assets & 771 & 7.957 & 3.165 & -1.924 & 14.114 \\
\hline Interest income & 767 & 1.586 & 1.431 & -1.050 & 28.160 \\
\hline Operating non-interest income & 268 & 1.164 & 1.375 & -4.218 & 12.504 \\
\hline Fee and commission income & 222 & 0.298 & 0.586 & -0.791 & 3.535 \\
\hline Trading income & 770 & 1.431 & 1.766 & -9.680 & 30.790 \\
\hline Non-operating income & 685 & -0.358 & 1.550 & -33.830 & 2.830 \\
\hline Cost to income & 765 & 65.072 & 34.997 & 9.470 & 499.510 \\
\hline Capital ratio & 775 & 9.225 & 11.288 & -22.740 & 98.510 \\
\hline ROA & 772 & 0.464 & 1.871 & -25.320 & 7.500 \\
\hline Credit activity & 773 & 40.642 & 21.544 & 0.000 & 99.860 \\
\hline Bank asset concentration & 664 & 58.236 & 18.469 & 20.668 & 100.000 \\
\hline \multicolumn{6}{|l|}{ ORIGINATORS } \\
\hline Log assets & 78 & 8.702 & 2.318 & 1.721 & 12.130 \\
\hline Interest income & 45 & 2.910 & 5.582 & 0.000 & 32.590 \\
\hline Operating non-interest income & 45 & 0.189 & 4.927 & -28.150 & 7.580 \\
\hline Fee and commission income & 23 & 0.243 & 4.800 & -36.508 & 4.684 \\
\hline Trading income & 18 & 1.751 & 2.187 & 0.017 & 7.688 \\
\hline Non-operating income & 44 & 14.303 & 24.320 & -0.120 & 129.760 \\
\hline Cost to income & 30 & 215.955 & 217.510 & 56.570 & 857.140 \\
\hline
\end{tabular}


Table 1, cont.

\begin{tabular}{l|r|r|r|r|r}
\hline Capital ratio & 78 & 20.437 & 27.535 & 1.090 & 84.970 \\
\hline ROA & 69 & 19.184 & 31.243 & -6.460 & 130.930 \\
\hline Credit activity & 62 & 45.370 & 25.088 & 0.470 & 80.270 \\
\hline Bank asset concentration & 69 & 46.897 & 16.959 & 20.668 & 80.745 \\
\hline TRADERS & & & & & \\
\hline Log assets & 652 & 7.076 & 2.973 & -3.230 & 14.463 \\
\hline Interest income & 640 & 1.147 & 1.541 & -8.890 & 11.560 \\
\hline Operating non-interest income & 236 & 7.827 & 19.016 & -9.474 & 242.797 \\
\hline Fee and commission income & 198 & 1.015 & 1.474 & -4.165 & 10.387 \\
\hline Trading income & 632 & 6.012 & 11.207 & -2.310 & 197.170 \\
\hline Non-operating income & 553 & -0.918 & 8.442 & -195.920 & 4.180 \\
\hline Cost to income & 619 & 78.010 & 66.911 & 0.000 & 982.540 \\
\hline Capital ratio & 663 & 17.384 & 20.493 & 0.140 & 100.000 \\
\hline ROA & 663 & 1.248 & 4.160 & -46.270 & 25.550 \\
\hline Credit activity & 641 & 29.110 & 21.837 & -0.170 & 93.370 \\
\hline Bank asset concentration & 595 & 67.361 & 18.708 & 20.668 & 93.365 \\
\hline
\end{tabular}

Source: own calculations based on the Bankscope database

The data from Table 1 suggest that there is a huge variation in the bank characteristics depending on the banking business model. This is reflected in the differences in almost all financial indicators between the types of banks. We observe that on the one hand, we have banks designed as traders with an interest income ratio of 1.5 , while on the other hand, banks designed as traditioners and originators with a ratio of 2.9. The neutrals are placed in the middle with an interest income of 1.6. These data seem to be consistent with the nature of the banking business and our classification. Banks that concentrate on traditional activities earn their income primarily from interest, whereas institutions oriented more towards investment banking, profit from other sources of income. There is also a discrepancy between the banks with respect to other income sources. The ratio of other operating income is the largest for traders, whereas it is the lowest for originators. Surprisingly, traditioners have a ratio of 1.03 , which is comparable to the ratio of neutrals. However, the ratio of traders and originators reflects their high involvement in the capital markets and securitization activities. Supposedly this is the reason why we found a high ratio of non-operating activities in this banking model. Due to the limited clarity of this high position, we might argue that this indicates the "hidden" risk of this banking model. In terms of the structure of non-interest income, the data indicate that the fee and commission income seems to be very important, particularly for 
traditioners and traders. Surprisingly, we do not observe a very high ratio of this income for neutrals and originators.

We also find that traditioners and neutrals were the most efficient institutions as measured by the ratio of cost to total income. This is surprising because the majority of the recent literature indicates that expanding banking income sources into non-traditional activities improves bank efficiency (DeYoung 1994; Rogers, 1998). At the same time, Buch et al. (2013) indicate that increasing the size of the institution increases the cost of its monitoring, which might negatively affect banks efficiency. Moreover, the data indicate that traders and originators are among the most profitable institutions, while neutrals are the least profitable. These results are in line with the existing literature that indicates investment activities have a larger margin than credit activity and thus allow banks to improve their profitability (Adrian and Shin, 2010b). We also observe a wide heterogeneity in the capital ratios between the specific banking models. We observe the highest ratio for originators and traders and the lowest ratio for neutrals. Traditioners are in the middle with a capital ratio of 10.2. The results are consistent with our expectations. The neutral model for the most part consists of institutions that have expanded heavily into foreign markets in recent years, so their asset growth strategy has also absorbed significant capital. The results for traders and originators reflect a favourable

Table 2

Summary statistics

\begin{tabular}{l|r|r|r|r|r}
\hline & No. of obs. & Mean & \multicolumn{1}{c|}{ Std. dev. } & \multicolumn{1}{c}{ Min. } & \multicolumn{1}{c}{ Max. } \\
\hline TRADITIONERS & & & & & \\
\hline Systemic risk indicator & 232 & 0.491 & 2.547 & 0.000 & 27.190 \\
\hline NEUTRALS & & & & & \\
\hline Systemic risk indicator & 179 & 0.307 & 1.741 & 0.000 & 15.550 \\
\hline TRADERS & & & & & \\
\hline Systemic risk indicator & 142 & 0.323 & 1.487 & 0.000 & 10.200 \\
\hline ORIGINATORS & & & & & \\
\hline Systemic risk indicator & 16 & 1.820 & 3.617 & 0.000 & 11.970 \\
\hline
\end{tabular}

The data represent the summary statistics for the financial distress measures for the mortgage crisis period of 2007-2009, grouped by the banking models of originators, traders, neutrals and traditioners. Classification is based upon the mean of various income sources: traditioners if the interest income is above the mean, and other source of income is below the mean; neutrals if the interest- and non-interest incomes are close to the mean; originators if the interest- and non-interest income are above the mean; and traders if the non-interest income is above the mean, and the interest income is below the mean for the types of activities exhibited by the major banks in a country.

Source: own calculations based on the V-Lab data 
performance in the capital markets. These results are interesting, though consistent with the existing studies. First, Gropp and Heider (2010) indicated that there is significant heterogeneity in the level of capital between the banks in various countries which is not explained by the capital requirements but rather by the bank specific characteristics. Second, Adrian and Shin (2010b), and Shleifer and Vishny (2010) showed that the capital of banks engaged in investment activities is highly correlated with the pricing of bank assets. In recent years the upward trend in mortgage securities has allowed these banks to achieve a high valuation and thus to exhibit substantial capital positions.

Table 2 presents the systemic risk indicator as a measure of financial distress in banks representing the individual banking models during the mortgage crisis of 2007-2009.

The data on financial distress present an interesting picture of bank risk. They show that originators are the most systemically important banks. It is apparent that these banks may experience severe financial distress due to two sources: the loss from lending activity, and the drop in value of invested securities. Surprisingly, we also find that the systemic importance index also indicates a higher value for traditioners than for traders. This might be because of the interconnectedness of traditional banks via the interbank market. For neutrals, it seems to be the lowest.

\section{EMPIRICAL SECTION}

\subsection{Model}

Initially we are interested in discovering the financial characteristics of the individual banking models.

For the first part of the analysis, we evaluate the probit model according to the following specification:

$$
\operatorname{Prob}\left(R_{i c t}\right)=\beta_{0}+\beta_{1} X_{i c t}+\varepsilon_{i c t}
$$

where $R_{i c t}$ is a business model assigned to a bank $i$ from a country $c$ at time $t$ from the period 1995-2006; $X_{\text {ict }}$ is a set of banking control variables including bank capital, cost efficiency, profitability, income structure and asset size, in addition to country control variables such as banking sector concentration; $\varepsilon_{i c t}$ is an error term. The balance sheet data are from the Bureau van Dijk. The data for country characteristics are from the World 
Bank Development Indicators Database. We run the regressions on the panel data covering 360 banks from 26 countries over the period 1995-2006. In addition, we include in our regressions the fixed effect with respect to individual years. In the robustness part of the article, we also include the fixed effect for a country to show that institutional features of countries do not alter significantly our main findings. This is because probably the individual models are partly a result of the country's individual features.

However to analyze the effect of the individual banking business models on a bank's financial distress, we employed the data on the mortgage crisis and run regressions for the sample period 2007-2009. Our model in this part of the paper is the following:

$$
S_{i c t}=\beta_{0}+\beta_{1} R_{i}+\beta_{2} X_{i c t}+\varepsilon_{i c t}
$$

where $S_{i c t}$ is a systemic risk measure of a bank $i$ from country $c$ at time $t$. We define systemic risk measures as the bailout dummy, the nationalization dummy, the systemic importance dummy and the systemic risk measure. The systemic risk indicators are from the $\mathrm{V}$-Lab. $R_{i}$ is the variable of our main interest, namely a proxy for the banking business models defined as "originator", "trader", "neutral", and "traditioner", and $X_{\text {ict }}$ proxies the country characteristics such as bank asset concentration and country GDP per capita. The regression is based on the panel data covering the mortgage crisis years 2007-2009. In all regressions we also include the fixed effects with respect to the individual years and countries.

\section{REGRESSION RESULTS}

\subsection{Banking models and their characteristics}

In this section we present the regression results for the probit model, whereby we estimate probability using the banking models for each classification of the banks based on the financial characteristics. In specification (1) we present the regression results while also including the general classification of the income sources, and in specification (2) we split the income into income from trading, and income from fees and commissions. The inclusion of the income source is important because, as argued, it also directly affects the cost efficiency, profitability, and capital ratio. In specifications (3) and (4) we run regressions on the sub-samples dividing the sample periods into 1999-2004 and 2004-2006. Such a division 


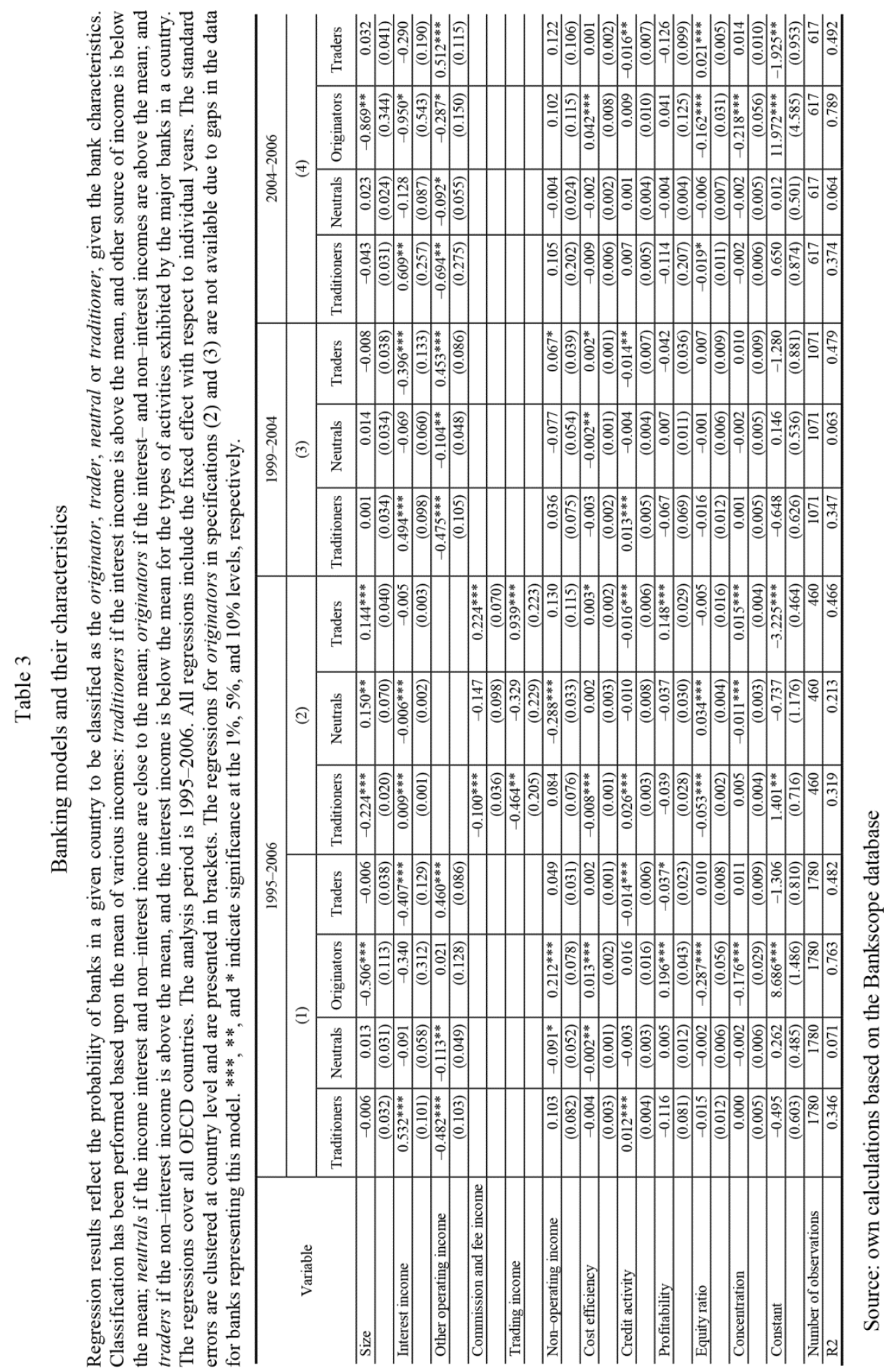


of the sample has been dictated by the different trends observed in the capital market over these time periods. In the first sub-period we observed the strong development of securitization, whose peak was reached in the second sub-period. Therefore we expect, particularly in the period of 2004-2006, to see significant differences between the individual banking models. Table 3 presents the results.

In specification (1) we observe that the majority of the income sources reflect the nature of the business of the individual banking strategies. The interest income appears as statistically significant and positive in the traditional model. This is similar to the credit activity variable. In the neutral model, we do not observe any trend toward any income source compared to the other banking business models. Consistent with their nature of business, originators are the banks that were heavily engaged in the credit business and used it partially to transform the loans into other assets. Surprisingly, we observe a positive, and statistically significant, coefficient of non-operating income for originators. This variable might indicate the importance of the non-standard banking transactions in this banking model. As suggested, this might indicate the "hidden" risk of originators. Finally, consistent with their business, we observe a positive, and statistically significant, coefficient for traders, which is in line with this banking model. In turn, we see that the interest income was of minor importance for traders. The results from specification (2) also support the nature of the banking business, however they provide a more detailed insight. We observe, for example, that traders have a very high share of both trading, and commission and fee income. Again, we do not find a statistical link for these variables with the neutral model.

From our perspective it is more interesting to see the financial features characterizing the individual banking strategies as well as the differences between them. Thus we can observe that neutral and traditional businesses seem to be the most efficient. This conclusion is supported by the negative coefficient of the efficiency ratio for these two banking models in specifications (1) and (2). The result for traditioners in specification (2) is interesting and might support the existing literature in that expanding banks' activities into non-traditional business may improve their efficiency. This finding is supported by the studies of DeYoung (1994) and Rogers (1998) who indicated that the increased amount of fee-based or non-traditional activities improved the efficiency of US banks in the late 1980s and 1990s. Similar results are obtained by Bos and Kolari (2005), for a large sample of European and US banks and by Lozano-Vivas and Pasiouras (2010), for 752 banks around the world. 
However, our results for originators and traders present the opposite conclusions. The cost efficiency ratio for these banks appears positive and statistically significant, suggesting the negative relationship between this variable and these banking models. These results imply that foregoing traditional activities in favour of non-traditional activities deteriorates efficiency. This result is consistent with DeYoung and Roland (2001), in terms of the US banks and with Rossi et al. (2009), in regard to the Austrian banks. This seems to suggest that though the non-interest activities have a higher margin, they generate higher costs. These costs are most likely associated with the technological advances that are difficult to share among different non-traditional businesses. In total, the above results suggest that diversifying bank activities toward non-interest activities may improve bank efficiency, but only to a certain extent. When the non-interest income starts to dominate banking business, efficiency drops as the costs of technology are likely to start to increase significantly. This result might indicate the nonmonotonic effect of non-interest activities on bank's performance.

Interestingly, our above conclusions hold, although we control for the size of banks. The size coefficient of neutrals is positive and statistically significant, which suggests that these banks were larger in size compared to other banks in specification (2). We find a similar effect for traders. We also find that traditioners and originators were smaller than neutrals and traders. Interestingly, the efficiency coefficients are not always consistent with the size of banks. This result might suggest that the asset structure decides about banks efficiency rather than the size. Moreover, we also observe in specifications (1) and (2) that originators and traders are more profitable than traditioners and neutrals. This supports the existing literature that indicates that capital market services are higher margin products and thus increase bank profitability (Adrian and Shin, 2010b; Rossi et al., 2009). Interesting results are also presented with the coefficients on capital ratios. They show in specifications (1) and (2) that the capital ratio coefficient is negative for originators and traditioners. This might be due to the nature of the business of these banks which was linked with credit activity, a highly regulated and capital intensive line of business. The negative capital ratio for originators is also consistent with recent studies. Affinito and Tagliaferri (2010) point out that riskier and less capitalized banks are more likely to engage in securitization. In turn, the capital ratio for neutrals is positive and statistically significant, which suggests that a well-balanced activity structure can allow banks to economize on the required capital. Surprisingly, we do not observe any effect of the trader model on the capital ratio. This is in line with the observations indicating that the capital ratio of these banks 
was sensitive to capital market movements, therefore the effects might have offset each other in our regression. This conclusion supports the result for specification (4) when we present the regression results only for the subperiod of 2004-2006. Because in this period banks profited from the high performance of global capital markets, we observe that the capital ratio is positively and significantly statistically related for the trader model. This supports the results of Adrian and Shin (2010), and Shleifer and Vishny (2010), who indicate that the capital ratio of trader banks moves with the performance of the capital markets. Finally, the result for the concentration ratio also presents interesting results. In specifications (1) and (2), we find that neutrals and originators evolved in a less concentrated market structure. This might suggest that declining margins and competition from other institutions forced these banks to search for additional yields (Allen and Santomero, 2001; Rajan, 2006). Surprisingly, we observed that the trader model originated in a highly concentrated environment.

\subsection{Banking business models and funding strategies}

Recent research has stressed the importance of bank liquidity as an important source for preventing bankruptcy during financial turbulence (Diamond and Rajan, 2005). This research considers two aspects: first, the type of funding source and, second, the maturity of the funding. DemirgüçKunt and Huizinga (2010) indicate that banks that fund their activities by non-deposit funds are riskier; however Allen et al. (2012), and Brunnermeier and Oehmke (2013) point out that in particular the banks that used repo instruments in their funding structure suffered from the crisis. In addition, the maturity of a bank's liability source is important. Gorton and Pennacchi (1990) claim that the role of a banking system is to issue liquid short-term debt claims against non-liquid assets. Such a structure improves liquidity management because deposits, for the most part of a retail nature, are unlikely to be withdrawn prematurely due to their public protection (Song and Thakor, 2007). However, Damar et al. (2013), Adrian and Shin (2010a) and Demirgüç-Kunt and Huizinga (2010) indicate that funding noninterest income by attracting short-term funding is the riskiest strategy because as the market drops, bank assets lose value and rolling-over debt may become problematic.

In this section we investigate the role of funding sources for individual banking models and the effect of these funding sources on the banks' riskreturn profile. For this reason we add to our analysis the liquidity ratio defined as the ratio of liquid assets to deposit and short-term funding, as 


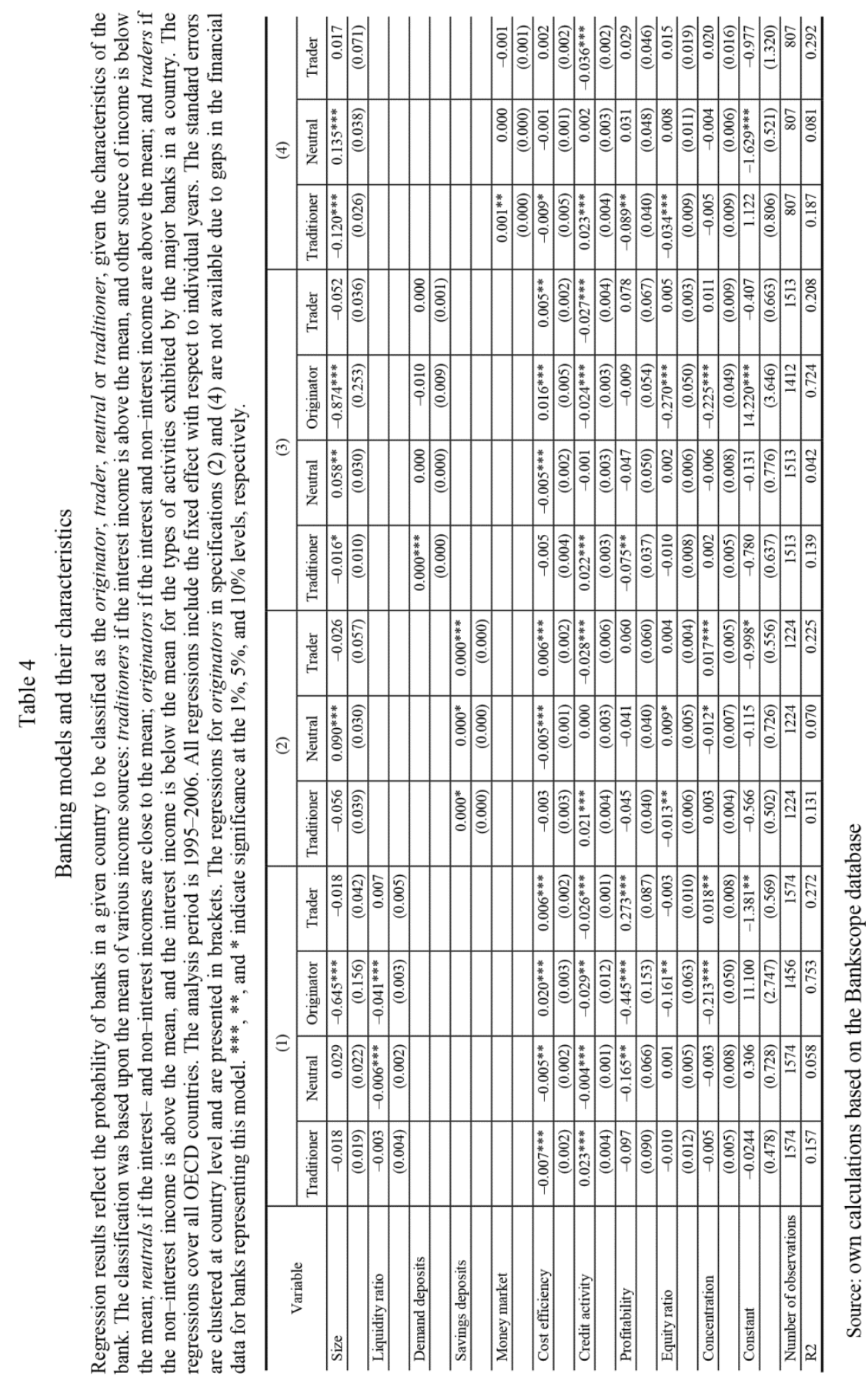


well as such sources of funds as: demand deposits, savings deposits, and money market funding. These variables are scaled by the total liabilities of the bank. Table 4 presents the results.

The regressions on the liquidity and funding strategies present interesting results. First, in specification (1) they indicate that individual banking models vary with respect to their liquidity. Specifically, we observe that banks engaged in credit activity (neutrals and originators) have a lower liquidity ratio. The ratio of liquid assets to deposit funding is negatively correlated with these banking strategies. This result is not surprising because of the long-term nature of bank assets. Surprisingly, we do not find any statistical significance for the liquidity ratio of traditioners.

Interestingly we also find in specifications (2)-(4), that banks vary significantly in their funding strategies. For example, we find that though the savings deposits are statistically significant in all banking models, they appear to be the most significant for the trader model. This seems to suggest that the trading banks funded their activities to a large extent by the issuance of long-term deposit claims. This has made the mortgage crisis worse because it has resulted in dangerous bank runs, as the example of Northern Rock has demonstrated.

In contrast, in the traditional model we find a statistically significant effect for the demand deposits. This is in line with the banking literature arguing that traditional banking business relies on issuing short-term claims and converting them into long-term assets (Gorton and Pennacchi, 1990; Kashyap et al., 2002). Surprisingly, we also find a positive effect from the short-term money market funding for traditioners and no such effect for the other banking models. This result might be a consequence of the internal capital market which allowed these banks to benefit from parent capital (Allen et al., 2014).

Overall, the results suggest that deposit funding was a significant source of funds for banks. This result is particularly important for trading banks which have significantly relied on wholesale funding (Brunnermeier and Pedersen, 2007). Such a funding structure increases the non-liquidity risk of this banking strategy coming from both sides: deposits and assets held.

\subsection{Robustness check}

\subsubsection{Does an income approach reflect the business of banks?}

Our banking models have been identified based on an income approach. However, identifying banking business models based on the interest and non-interest income might be too general to say that a bank specializes in a 
specific type of activity such as securitization or trading. The problem becomes even worse as more detailed structure of income for most of our banks is not available. Moreover, comparing various banking incomes between countries would also be very difficult because of the accounting practices. Since the proper identification of banks representing a specific banking model is crucial for our conclusions, we provide the robustness check to demonstrate that our approach for identifying banks based on the level of interest and non-interest income reflects the activities of the banks in our sample. Therefore we include asset structure variables into our regressions. Our intuition is that the asset structure of a specific banking model should reflect the type of business conducted by a bank.

More specifically, we expect that traders and traditioners will have the most concentrated asset structure. The assets of the former should predominantly consist of the trading securities, whereas the latter should mainly have a credit activity. On the other hand, we should see a more diversified asset structure for neutrals and originators, with the former banks the most diversified.

Table 5 presents the regression results after controlling for various types of assets such as: total earning assets, trading securities, investment securities, equity investments, and credit activity.

The data present important implications. First, in specification (1), they show that originators and traditioners exhibited the highest share of earning assets. Specifically for originators this might seem to suggest that credit activity was still an important part of their banking business. For these banks, the non-operating income becomes statistically significant, which might indicate the previously mentioned securitization activity. Interestingly, we do not observe any significant link between the coefficient of earning asset and the trader model, though we observe a statistically significant relationship for other operating income. Surprisingly we also observe that neutrals exhibit a negative correlation with the majority of the variables proxying for the income sources as well as with the asset variable. This confirms that these banks had the most balanced structure for their activities compared to other banking models. Second, in specification (2), we observe that the coefficient of trading securities exhibited a positive and statistical correlation only for the trader model. This result is consistent with our expectations and with the nature of the business of this banking model. More importantly, this result seems to suggest that traders exhibit a very specialized structure compared to the other banking models, particularly originators. Compared to the other banks, they also had much less investment securities in their asset structure, which might also explain their 


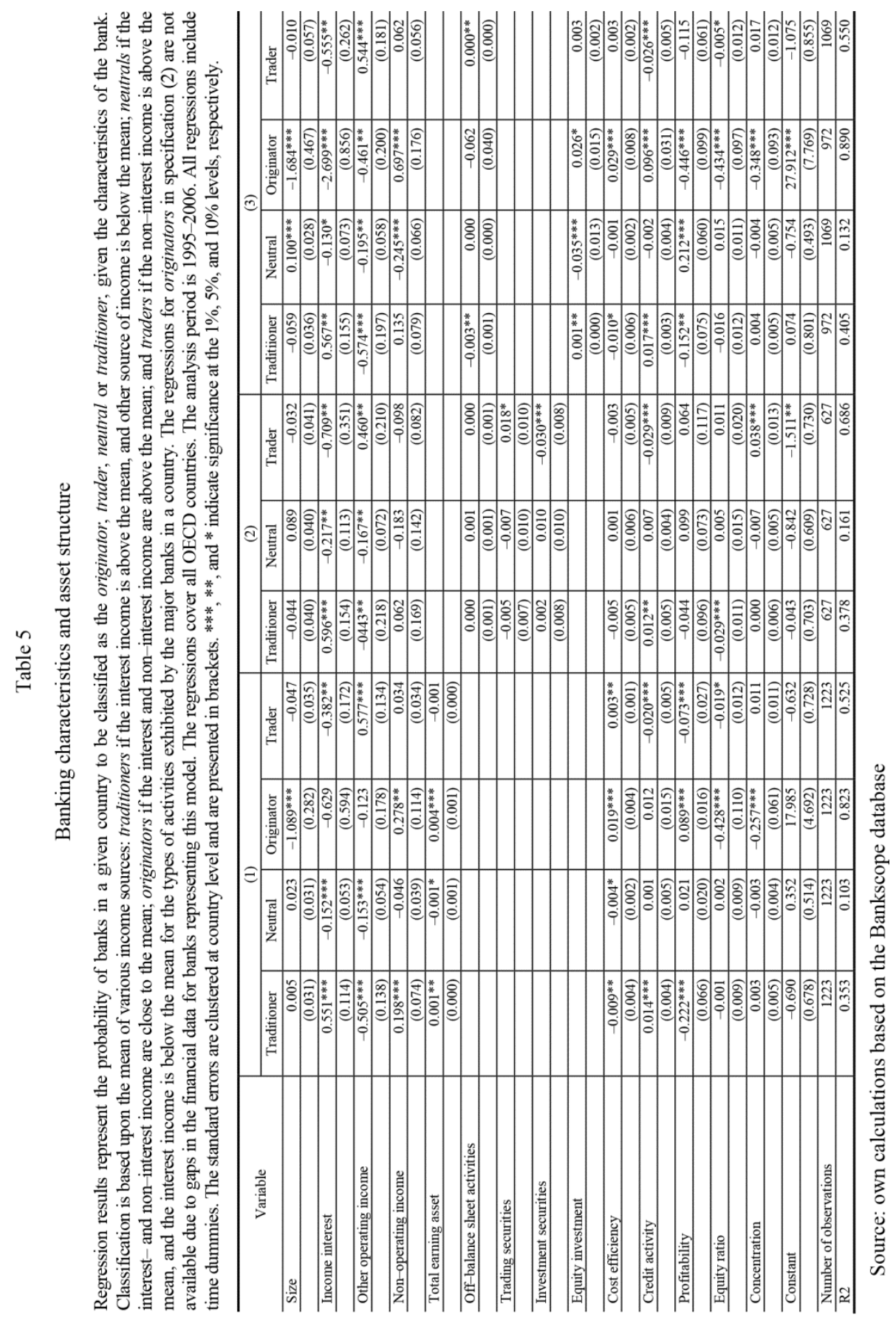


liquidity problems once the mortgage crisis began. For neutrals and traditioners we do not observe any significant implications of trading and investment securities. This might suggest that these banking models exhibited securities structures similar to the other groups except for traders. For originators, the results are not available due to the gaps in the financial variables for these banks. Finally, in specification (3), we control for bank equity investments. This variable mainly represents ownerships in the associated companies. Such investments can offer banks advantages but also significant risks. On the one hand, it grants bank access to capital when it is needed. Such a situation happened during the mortgage crisis in the emerging countries when distressed banks from western economies benefited from the favourable financial conditions of their foreign subsidiaries by receiving dividends (Hryckiewicz and Kowalewski, 2010). On the other hand, if both institutions are in distress, there might be negative consequences for the parent banks. Alternatively, the equity investments may also be a proxy for a bank's investment in SPV. Under the accounting standards, investment in SPV, especially when it is dependent on the parent bank, must be consolidated with a parent balance sheet. As we can observe, originators and traditioners exhibit a positive and statistically significant coefficient for equity investment. The result for originators might be partially due to their investment in SPV associated with securitization transactions. However the result for traditioners might indicate a bank's participation in the transactions that they financed. Interestingly, we notice a negative and statistically significant coefficient of this variable for neutrals, which suggests the low importance of this type of investment in the bank asset structure compared to other banking models.

In conclusion, our results suggest that the model most closely linked with the capital market performance was the trader model. It also seemed to have a low share of investment securities, which might explain its liquidity problems and the contagion effects which occurred during the mortgage crisis.

Other results are consistent with our previous regressions. In specifications (1) and (3), we find that neutrals and traditioners are the most efficient, while traders and originators are the least efficient. In addition, in specification (3) we also find that neutrals are the most profitable institutions. This supports the recent studies of Boot and Ratnovski (2015) and Altunbas et al. (2011) which claim that non-traditional activities may benefit banks. Alternatively, the result might also suggest that banks have achieved an equilibrium in their activities which allows them to profit from a good diversification between traditional and non-traditional activities. 
Interestingly, in specification (1) we also note a positive relationship between the profitability variable and originator model, but only once we control for the total earning assets. When we include the equity investment variable, the sign of profitability variable changes into negative. This may suggest that the costs associated with the securitization are significant. Interestingly, in specifications (1) and (3), once we consider the asset structure of the banks, we find that traders and originators had a lower capital ratio, suggesting that their assets were riskier than other banking strategies. This is consistent with the wide scope of recent empirical studies (Demirgüç-Kunt and Huizinga, 2010; Brunnermeier et al., 2012).

\subsubsection{Does a country's institutional structure change the results?}

According to the existing literature, the regulatory and institutional features might play an important role in explaining banks activities (Demirgüç-Kunt and Huizinga, 2010). Therefore in this subsection we check the robustness of our results by including the country fixed-effect capturing the uncontrolled country specific characteristics. Thus our regression will rely on the probit estimations for the panel bank-level data including the country and year fixed effect. The sample period remains the same and covers the years between 1995 and 2006. Other bank-level characteristics are included as in the previous regressions. Table 6 presents the regression results.

The regression results indicate that our main effects with respect to the individual banking models do not change significantly. Consistently with the previous results, we find that the traditional and neutral models are the most efficient while the originator model is less efficient than the other models. Moreover, we also find that the originator model is very profitable, which is in line with our previous results. This effect supports the existing studies, which indicate that non-interest income negatively affects cost efficiency, but increases profit efficiency (Rossi et al., 2009). However the profitability coefficient changes the sign for the trader model compared to our previous results for which we documented a positive effect. Though the result is statistically significant at the $10 \%$ significance level, it most likely suggests that certain institutional and regulatory features such as higher capital requirements may impede banks profitability once banks specialize solely in trading. The results for the capital ratio present similar conclusions as in the previous subsections. We find that traditioners and originators exhibit a lower capital ratio, which is mainly an effect of their involvement in credit 
Table 6

Robustness check

Regression results reflect the probability of banks in a given country to be classified as the originator, trader, neutral or traditioner, given the individual characteristics of the bank. Classification is based upon the mean of various income sources: traditioners if the interest income is above the mean, and other source of income is below the mean; neutrals if the interest- and non-interest incomes are close to the mean; originators if the interest and non-interest income are above the mean; and traders if the noninterest income is above the mean, and the interest income is below the mean for the types of activities exhibited by the major banks in a country. The regressions cover banks in all OECD countries. The analysis period is 1995-2006. All regressions include the fixed effects with respect to country and year. The standard errors are clustered at country level and are presented in brackets. ${ }^{* * *}, * *$, and $*$ indicate significance at the $1 \%, 5 \%$, and $10 \%$ levels, respectively.

\begin{tabular}{l|r|r|r|r}
\hline & Traditioner & Neutral & \multicolumn{1}{c|}{ Originator } & \multicolumn{1}{c}{ Trader } \\
\hline Size & -0.056 & $0.100^{* * *}$ & $-6.369^{* *}$ & -0.037 \\
\hline Income interest & $(0.043)$ & $(0.032)$ & $(2.511)$ & $(0.070)$ \\
\hline & $0.464^{* * *}$ & $-0.112^{* *}$ & $-4.726^{*}$ & $-0.320^{* *}$ \\
\hline Other operating income & $(0.087)$ & $(0.049)$ & $(2.810)$ & $(0.131)$ \\
\hline & $-0.519^{* * *}$ & $-0.089^{*}$ & $1.063^{* * *}$ & $0.475^{* * *}$ \\
\hline Non-operating income & $(0.099)$ & $(0.043)$ & $(0.094)$ & $(0.090)$ \\
\hline & 0.050 & -0.078 & 0.114 & 0.071 \\
\hline Cost efficiency & $(0.068)$ & $(0.051)$ & $(0.323)$ & $(0.046)$ \\
\hline & $-0.004 *$ & $-0.002^{* *}$ & $0.112^{* *}$ & 0.002 \\
\hline Credit activity & $(0.003)$ & $(0.001)$ & $(0.044)$ & $(0.001)$ \\
\hline Profitability & $0.012^{* *}$ & -0.001 & $0.204^{* *}$ & $-0.016^{* *}$ \\
\hline & $(0.005)$ & $(0.005)$ & $(0.100)$ & $(0.007)$ \\
\hline Equity ratio & -0.077 & -0.003 & $3.199^{* *}$ & $-0.044^{*}$ \\
\hline & $(0.064)$ & $(0.013)$ & $(1.366)$ & $(0.025)$ \\
\hline Concentration & $-0.023^{* *}$ & $0.015^{* *}$ & $-2.269^{* * *}$ & 0.001 \\
\hline & $(0.010)$ & $(0.007)$ & $(0.577)$ & $(0.007)$ \\
\hline Constant & -0.011 & -0.004 & $-3.322^{* * *}$ & $0.031^{* * *}$ \\
\hline & $(0.008)$ & $(0.007)$ & $(1.286)$ & $(0.012)$ \\
\hline Number of observations & 0.847 & $-1.328^{* *}$ & $149.823^{* * *}$ & -1.814 \\
\hline R2 & $(0.619)$ & $(0.609)$ & $(57.528)$ & $(1.154)$ \\
\hline & 1772 & 1749 & 828 & 1625 \\
\hline
\end{tabular}

Source: own calculations based on the Bankscope database

activity (for both banking models, the coefficient of credit activity appears in the regressions as statistically significant). In line with the previous results we find that neutrals are better capitalized than the other banking models. 


\subsection{How risky are individual banking models?}

In this section we argue that some banking strategies are more sensitive to financial turbulences, whereas others are less sensitive. We claim that riskiness is a function of the financial characteristics such as activity type, asset structure and funding strategies. For example, Diamond and Rajan (2005), Brunnermeier and Pedersen (2007), and Gorton and Metrick (2012) indicate that the originate-and-distribute model was one of the determinants of the mortgage crisis. Demirgüç-Kunt and Huizinga (2010), show that the riskiest model is the investment banking model, whereby banks fund their non-interest income with short-term non-deposit funds. The majority of the researchers agree that the least risky model seems to be the traditional one (DeJonghe, 2010). This model, however, has been demonstrated as probably one of the least profitable (Baele et al., 2007). In the existing literature there is no agreement regarding any model that improves profitability whilst at the same time increasing risk for the banking sector. For this reason we regress four systemic risk measures on the individual banking models and certain country variables. For our analysis we used four systemic risk measures which have been widely used in the existing literature. These are: a) a bailout dummy, a variable equal to one if a bank received a bailout during financial crisis, and zero otherwise, b) a nationalization dummy, a variable equal to one if a bank has been nationalized during a financial crisis, and zero otherwise, c) bank's systemic importance dummy that is equal to one if a bank has been classified as systemic important by V-Lab, and zero otherwise, and d) bank's systemic importance indicator as defined by VLab. Because each model is a function of its financial characteristics, we do not include the individual bank variables in the regressions because this could lead to the multicollinearity problem. However we control for the size of each bank. In each regression we included the fixed effect with respect to the country characteristics as well as the year. The analysis covers the period 2007-2009. Table 7 presents the results.

The estimation results present very interesting implications. They are consistent with the academic literature indicating that originators and traders are the riskiest banking models. Interestingly, the traditional and neutral models seem to be the least risky among the models. These results seem to indicate two important conclusions. First, the banking specialization in capital market activities increases risk, possibly because of the positive correlation of the bank assets within a banking system, as well as the greater volatility of bank performance. In addition, we observe with interest that the financial support dummies which are ex-post risk measures are positively 
Table 7

Banking models and their riskiness

The regression results reflect the panel estimations for the contribution of the individual banking model to the bank's risk. The banking models include the originator, trader, neutral, and traditioner. Classification is based upon the mean of various income sources: traditioners if the interest income is above the mean, and other source of income is below the mean; neutrals if the interest- and non-interest incomes are close to the mean; originators if the interest and non-interest income are above the mean; and traders if the non-interest income is above the mean, and the interest income is below the mean for the types of activities exhibited by the major banks in a country. The regressions cover all OECD countries. The analysis period is 2007-2009. All regressions include the fixed effects with respect to individual countries and years. The standard errors are clustered at country level. ***, **, and * indicate significance at the $1 \%, 5 \%$, and $10 \%$ levels, respectively.

\begin{tabular}{l|r|r|r|r}
\hline Variables/Models & $\begin{array}{c}\text { Bailout } \\
\text { dummy }\end{array}$ & $\begin{array}{c}\text { Nationalization } \\
\text { dummy }\end{array}$ & $\begin{array}{c}\text { Systemic } \\
\text { importance } \\
\text { dummy }\end{array}$ & $\begin{array}{c}\text { Systemic } \\
\text { risk measure }\end{array}$ \\
\hline Size & 0.050 & 0.032 & $0.054^{* * *}$ & $0.167^{* * *}$ \\
\hline Concentration & $(0.027)$ & $(0.016)$ & $(0.010)$ & $(0.057)$ \\
\hline GDP per capita & $-0.007^{* *}$ & $-0.006^{* *}$ & $-0.017^{* *}$ & 0.000 \\
\hline & $(0.002)$ & $(0.001)$ & $(0.007)$ & $(0.004)$ \\
\hline Neutrals & 0.000 & $0.000^{* *}$ & 0.000 & $0.000^{* *}$ \\
\hline & $(0.000)$ & $(0.000)$ & $(0.000)$ & $(0.000)$ \\
\hline Traders & 0.009 & 0.018 & -0.042 & -0.164 \\
\hline & $(0.024)$ & $(0.027)$ & $(0.047)$ & $(0.171)$ \\
\hline Originators & $0.060^{* * *}$ & $0.022^{* * *}$ & 0.030 & 0.660 \\
\hline Constant & $(0.008)$ & $(0.002)$ & $(0.069)$ & $(0.578)$ \\
\hline & 0.086 & 0.124 & $0.283^{* *}$ & $0.481^{* *}$ \\
\hline Number of observations & $(0.133)$ & $(0.127)$ & $(0.108)$ & $(0.231)$ \\
\hline R2 & -0.289 & -0.173 & 0.621 & $-1.167^{* *}$ \\
\hline
\end{tabular}

Source: own calculations based on central banks' reports and V-lab database

related with the trader model; however the systemic importance measures which can be viewed as ex-ante risk measures, are related with the originator model. This might indicate two issues. First, the greatest ex-ante risk comes from originators, possibly because of the correlation between two income sources: losses from the lending activity as well as the drop in the value of securities. However the results indicate that ex-post traders exhibit the greatest losses. This is because of the ex-ante risk, which is difficult to monitor by traders. Because of the favourable financial performance during the economic expansion, the risk measure was very favourable for traders for a long time. The result suggests that the drop in capital value in this banking model is highly correlated with the stock market performance. Moreover, the bad situation of these banks might be fuelled by 
their liquidity problems, as the asset they hold becomes non-liquid during the downturn in capital market. This is also why these banks suffer the most once the crisis arrives. Second, the regression results also document that banks may benefit to some extent from the trading activities without significantly increasing a bank's risk. This is supported particularly by the neutral model. This is in line with Boot and Ratnovski (2015), who demonstrate that a low level of investment activities may improve bank efficiency without significantly increasing risk. Thus, the recent regulatory recommendations to reinstate the Glass-Steagall Act seem to be excessive and consequently may increase bank risk (see for example Barth et al., 2008). We also find that the larger the bank, the riskier it is. This is also consistent with the existing studies indicating that banks tend to grow in size to become systemically important institutions and thus able to follow riskier strategies (Boyd and Runkle, 1993; De Nicolo and Kwast, 2002). Finally, we find that higher concentration is negatively related with bank risk-taking, as banks with greater power are more easily monitored (Beck et al., 2006). We also find that more developed countries have more systemically important banks, which reflects the result of the systemic risk measure.

\section{CONCLUSIONS}

The aim of our study was to determine the features of various banking strategies and to find such a banking model which would allow banks to remain profitable, at the same time without increasing risk significantly. We argue that the recently imposed regulations in the banking sector may increase banking sector risk not allowing them to earn sufficient profits. Barth et al. (2008) demonstrate that greater capital regulations impair profitability and lead to hidden risk, which is reflected in the capital arbitrage behaviour of banks.

Our results present interesting conclusions. By dividing the sample banks based on the types of activities, our results suggest that there was significant heterogeneity among the banks following the various business models. This heterogeneity has been reflected in such financials as the asset structure, funding strategies, cost efficiency, profitability, and capital ratios, as well as the contribution of these banks to the systemic risk. The regression results indicate that banks with a low level of non-interest activities were more cost efficient than banks with a higher level. Furthermore, we find that nontraditional activities allow banks to improve their efficiency insofar as they remain within their traditional business. As the non-traditional businesses start to dominate banking activities, the costs seem to drastically increase, making these banks less efficient. This is because the non-interest business 
is more technologically advanced and requires significant resources to invest on a regular basis. Furthermore, the non-traditional business, having a higher margin, allows these banks to achieve a higher profit efficiency than is possible for banks with a large share of traditional business. Thus, traders and originator banks tend to be more profitable than the traditional banking models. Moreover, our results tend to suggest that non-traditional activities allow banks to economize on their regulatory capital. Thus, banks specializing in traditional business often seem to be less capitalized compared to other banking models. Importantly, in the latter part of the paper, we find that the capital level does not indicate the risk of the banking models which were heavily involved in trading. This confirms the existing studies, which indicate that the capitalization of banks involved in volatile capital markets is highly cyclical and vulnerable to poor market performance (Brunnermeier et al., 2012; Shleifer and Vishny, 2010). Moreover, we find that the majority of global banks retained their commercial business on the funding side, remaining highly dependent on the deposit market. This has also likely fuelled the liquidity problems of these banks.

The important contribution of our study is the assessment of a bank's risk given the banking model it follows. These results indicate that the banks in which non-interest income dominates are the riskiest. Taking into consideration various risk measures as proxies for the financial distress of a bank during the mortgage crisis, we indicate that the financial support dummies, which are ex-post risk measures, are positively related with the trader model. However the systemic importance measures, which can be viewed as ex-ante risk measures, are significantly correlated with the originator model. The result suggests that the greatest risk seems to be generated by the trader model, though this risk is not observable during the expansion period. In turn, the originator model generates the highest risk in normal times, however it will not materialize as much during the downturn period compared to the trader model.

These results present interesting policy implications. They indicate that the recent regulatory recommendations to reinstate the Glass-Steagall Act seem excessive and consequently may increase the bank risk (see, for example, Barth et al., 2008). This is also in line with the recent empirical results which indicate that non-traditional activities do not alter the higher risk for the banking sector once they do not dominate the banking business. Moreover, our results indicate that the neutral model allows banks to remain profitable without a significant increase-risk. This is because banks profit from a well-balanced diversification. This result indicates that we should restrict risky banking activities once a certain threshold of non-traditional business in the structure of the bank, especially trading, has been reached. 


\section{APPENDIX}

Table A1

\begin{tabular}{|c|c|c|}
\hline Variable & Description & Source \\
\hline Profitability & Net income to average assets (\%) & Bankscope \\
\hline Capital ratio & Book capital to total assets (\%) & Bankscope \\
\hline Size & Total assets (USD million), logarithmized & Bankscope \\
\hline Activity & Net loans to total assets $(\%)$ & Bankscope \\
\hline Efficiency & Non-interest expenses as a share of operating income (\%) & Bankscope \\
\hline Interest income & Income interest as a share of bank's average asset (\%) & Bankscope \\
\hline $\begin{array}{l}\text { Other operating } \\
\text { income }\end{array}$ & $\begin{array}{l}\text { Income from other bank's operating activities (trading, } \\
\text { commission, fee, insurance income) except from the } \\
\text { interest as a share of bank's average assets }\end{array}$ & Bankscope \\
\hline $\begin{array}{l}\text { Non-operating } \\
\text { income }\end{array}$ & $\begin{array}{l}\text { Income from other bank's non-operating activities as a } \\
\text { share of average assets }\end{array}$ & Bankscope \\
\hline $\begin{array}{l}\text { Commission and fee } \\
\text { income }\end{array}$ & $\begin{array}{l}\text { Commission and fee income as a share of bank's average } \\
\text { assets }\end{array}$ & Bankscope \\
\hline Trading income & Trading income as a share of bank's average assets & Bankscope \\
\hline Trading securities & $\begin{array}{l}\text { Securities classified as held for trading, including } \\
\text { government securities as a share of bank's average assets. } \\
\text { They are reported at a fair value. }\end{array}$ & Bankscope \\
\hline $\begin{array}{l}\text { Investment } \\
\text { securities }\end{array}$ & $\begin{array}{l}\text { Securities available for sale as a share of bank's average } \\
\text { assets. They are reported at fair value. }\end{array}$ & Bankscope \\
\hline $\begin{array}{l}\text { Off-balance sheet } \\
\text { activities }\end{array}$ & $\begin{array}{l}\text { Asset that the bank does not have a control but where it } \\
\text { may have some exposure to losses - for which it is most } \\
\text { likely being paid a fee or is remunerated in some other way. } \\
\text { Expressed as a ratio of a bank's average assets }\end{array}$ & Bankscope \\
\hline Mortgage assets & Value of mortgage loans as a share of bank's average assets & Bankscope \\
\hline Other loans & $\begin{array}{l}\text { Loans other than the mortgage loans as a share of bank's } \\
\text { average assets }\end{array}$ & Bankscope \\
\hline Equity investment & $\begin{array}{l}\text { Investment in associated companies as a share of a bank's } \\
\text { average assets }\end{array}$ & Bankscope \\
\hline Other investment & $\begin{array}{l}\text { Investment other than financial investment as a share of } \\
\text { bank's average assets }\end{array}$ & Bankscope \\
\hline Demand deposits & Demand deposits as a share of bank's average liabilities & Bankscope \\
\hline Savings deposits & Savings deposits as a share of bank's average liabilities & Bankscope \\
\hline Money market & $\begin{array}{l}\text { Certificates of deposits, commercial papers, and other } \\
\text { short-term money market instruments as a share of bank's } \\
\text { average liabilities }\end{array}$ & Bankscope \\
\hline Liquidity ratio & Liquid assets in relations to deposit and short-term funding & Bankscope \\
\hline Concentration ratio & $\begin{array}{l}\text { Assets of three largest banks as a share of the assets of all } \\
\text { commercial banks }\end{array}$ & World Bank \\
\hline GDP growth & $\begin{array}{l}\text { Annual percentage growth rate of GDP at market prices } \\
\text { based on constant local currency }(\%)\end{array}$ & World Bank \\
\hline Inflation & $\begin{array}{l}\text { Annual percentage change in consumer price index, } \\
\text { logarithmized }\end{array}$ & World Bank \\
\hline
\end{tabular}




\section{REFERENCES}

Acharya, V. V, Gromb, D., Yorulmazer, T., Imperfect Competition in the Interbank Market for Liquidity as a Rationale for Central Banking, "American Economic Journal: Macroeconomics", 4(2), pp.184-217, 2012.

Acharya, V., Hasan, I., The Effects of Focus and Diversification on Bank Risk and Return: Evidence from Individual Bank Loan Portfolios, Working Paper No. FIN-01, (July), New York University, New York 2001.

Acharya, V. V, Pedersen, L. H., Philippon, T., Richardson, M., Measuring Systemic Risk, 29(May), pp.1-46, New York 2010.

Acharya, V., Richardson, M., P., Causes of the Financial Crisis, "Critical Review", 21 (2 \& 3), pp. 195-210, 2009.

Adrian, T., Shin, H. S., Liquidity and leverage, "Journal of Financial Intermediation", 19(3), pp. 418-437, 2010a.

Adrian, T., Shin, H. S., The Changing Nature of Financial Intermediation and the Financial Crisis of 2007-2009, "Annual Review of Economics", 2(September)", pp. 603-618, 2010b.

Affinito, M., Tagliaferri, E., Why Do (Or Did?) Banks Securitize Their Loans? Evidence from Italy, "Journal of Financial Stability", 6(4), pp. 189-202, 2010.

Allen, F., Babus, A., Carletti, E., Asset Commonality, Debt Maturity and Systemic Risk, "Journal of Financial Economics", 104(3), pp. 519-534, 2012.

Allen, F., Hryckiewicz, A., Kowalewski, O., Tumer-Alkan, G., 2014, Transmission of Bank Liquidity Shocks in Loan and Deposit Markets: The Role of Interbank Borrowing and Market Monitoring, "Journal of Financial Stability", 15(December), pp. 112-126.

Allen, L., Jagtiani, J., The Risk Effects of Combining Banking, Securities, and Insurance Activities, "Journal of Economics and Business", 52(6), pp. 485-497, 2000.

Allen, F., Santomero, A. M., What Do Financial Intermediaries Do? "Journal of Banking and Finance", 25(2), pp. 271-294, 2001.

Altunbas, Y., Manganelli, S., Marques-Ibanez, D., Bank Risk During The Financial Crisis. Do Business Models Matter? Working Paper Series No 1393, European Central Bank, Frankfurt am Main 2011.

Baele, L., De Jonghe, O., Vander Vennet, R., Does the Stock Market Value Bank Diversification? "Journal of Banking and Finance", 31(7), pp. 1999-2023, 2007.

Barth, J. R., Caprio, G., Levine, R., Bank Regulations are Changing: For Better or Worse?, "Comparative Economic Studies", 50(4), pp. 537-563, 2008.

Beck, T., Demirgüç-Kunt, A., Levine, R., Bank Concentration, Competition, and Crises: First Results, "Journal of Banking \& Finance", 30(5), pp. 1581-1603, 2006.

Beltratti, A., Stulz, R. M., The Credit Crisis Around the Globe: Why Did Some Banks Perform Better?, 105(1), pp. 1-17, 2012.

Boot, A., Ratnovski, L., Banking and Trading, "Review of Finance", forthcoming, 2015.

Boot, A., Thakor, A., Can Relationship Banking Survive Competition? The Journal of Finance, 55(2), pp. 679-713, 2000. 
Bos, J. W. B., Kolari, J. W., Large Bank Efficiency in Europe and the United States: Are There Economic Motivations for Geographic Expansion in Financial Services? "The Journal of Business", 78(4), pp. 1555-1592, 2005.

Boyd, J. H., Runkle, D. E., Size and Performance of Banking Firms: Testing the Predictions of Theory, "Journal of Monetary Economics", 31(1), pp. 47-67, 1993.

Brunnermeier, M. K., Dong, G., Palia, D., Banks' Non-Interest Income and Systemic Risk, AFA 2012 Chicago Meetings Paper, 2012.

Brunnermeier, M. K., Oehmke, M., The Maturity Rat Race, "The Journal of Finance", 68(2), pp. 483-521, 2013.

Brunnermeier, M. K., Pedersen, L. H., Market Liquidity and Funding Liquidity, "Review of Financial Studies", 22(6), pp. 2201-2238, 2007.

Brunnermeier, M. K., Sannikov, Y., A Macroeconomic Model with a Financial Sector, Unpublished Manuscript, pp. 1-52, 2011.

Buch, C. M., Koch, C. T., Koetter, M., Do Banks Benefit from Internationalization? Revisiting the Market Power-Risk Nexus, "Review of Finance", 17(4), pp. 1401-1435, 2013.

Cifuentes, R., Ferrucci, G., Shin, H. S., Liquidity Risk and Contagion, "Journal of the European Economic Association", 3(2-3), pp. 556-566, 2005.

Damar, H. E., Meh, C. A., Terajima, Y., Leverage, Balance-sheet size and Wholesale Funding, "Journal of Financial Intermediation", 22(4), pp. 639-662, 2013.

Davis, E., Karim, D., Comparing Early Warning Systems for Banking Crisis, "Journal of Financial Stability", 4(2), pp. 89-120, 2008.

DeJonghe, O., Back to the Basics in Banking? A Micro-analysis of Banking System Stability, "Journal of Financial Intermediation", 19(3), pp. 387-417, 2010.

De Nicolo, G., Kwast, M. L., Systemic Risk and Financial Consolidation: Are They Related? "Journal of Banking and Finance", 26(5), pp. 861-880, 2002.

Demirgüç-Kunt, A., Huizinga, H., Bank Activity and Funding Strategies: The Impact on Risk and Returns, "Journal of Financial Economics", 98(3), pp. 626-650, 2010.

DeYoung, R., Fee-based Services and Cost Efficiency in Commercial Banks. Proceedings of Conference on Bank Structure and Competition No 47, Federal Reserve Bank of Chicago, 1994.

DeYoung, R., Roland, K. P., Product Mix and Earnings Volatility at Commercial Banks: Evidence from a Degree of Total Leverage Model, "Journal of Financial Intermediation", 10(1), pp. 54-84, 2001.

DeYoung, R., Torna, G., Nontraditional Banking Activities and Bank Failures during the Financial Crisis, "Journal of Financial Intermediation", 22(3), pp. 397-421, 2013.

Diamond, D. W., Rajan, R. G., Liquidity Shortages and Banking Crises, "Journal of Finance", 60(2), pp. 615-647, 2005.

Diamond, D. W., Rajan, R. G., Fear of Fire Sales, Illiquidity Seeking, and Credit Freezes, "The Quarterly Journal of Economics", 126(2), pp. 557-91, 2011.

Duffie, D., Gârleanu, N., Risk and Valuation of Collateralized Debt Obligations, "Financial Analysts Journal", 57(1), pp. 41-59, 2001. 
Elsas, R., Krahnen, J. P., Is Relationship Lending Special? Evidence from credit-file Data in Germany, "Journal of Banking \& Finance", 22(10-11), pp. 1283-1316, 1998.

Feng, G., Serletis, A., Efficiency, Technical Change, and Returns to Scale in Large US Banks: Panel Data Evidence from an Output Distance Function Satisfying Theoretical Regularity, "Journal of Banking and Finance", 34(1), pp. 127-138, 2010.

Foos, D., Norden, L., Weber, M., Loan Growth and Riskiness of Banks, "Journal of Banking and Finance", 34(12), pp. 2929-2940, 2010.

Franke, G., Krahnen, J. P., Center for Financial Studies, Working Paper October, 49, Frankfurt am Main 2008.

Fraser, D. R., Madura, J., Weigand, R. a., Sources of Bank Interest Rate Risk, "The Financial Review", 37(3), pp. 351-367, 2002.

Gorton, G. B., Pennacchi, G. G., Financial Intermediaries and Liquidity Creation, "Journal of Finance", 45(1), pp. 49-71, 1990.

Gorton, G., Metrick, A., Securitized Banking and the Run on Repo, "Journal of Financial Economics", 104(3), pp. 425-451, 2012.

Gropp, R., Heider, F., The Determinants of Bank Capital Structure, "Review of Finance", 14(4), pp. 587-622, 2010.

Hördahl, P., King, M. R., Development in Repo Markets during the Financial Turmoil, "Quarterly Review", Bank for International Settlement, Basel 2008.

Hryckiewicz, A., What Do We know about the Government Interventions in the Banking Sector? The Assessment of Various Bailout Programs on Bank Behavior, "Journal of Banking and Finance", 46(September), pp.246-265, 2014.

Hryckiewicz, A., Kowalewski, O., Economic Determinates, Financial Crisis and Entry Modes of Foreign Banks into Emerging Markets, "Emerging Markets Review", 11(3), pp. 205-228, 2010.

Huang, R., Ratnovski, L., The Dark Side of Bank Wholesale Funding, "Journal of Financial Intermediation", 20(2), pp.248-263, 2011.

Hughes, J. P., Mester, L. J., Who Said Large Banks Don't Experience Scale Economies? Evidence from a Risk-return-driven Cost Function, "Journal of Financial Intermediation", 22(4), pp. 559-585, 2013.

Ivashina, V., Scharfstein, D., Bank Lending during the Financial Crisis of 2008, "Journal of Financial Economics", 97(3), pp. 319-338, 2010.

Jiangli, W., Pritsker, M., The Impacts of Securitization on US Bank Holding Companies, Working Paper Series No 1097, Federal Reserve Bank of Chicago, 2008.

Kalemli-Ozcan, S., Sorensen, B., Yesiltas, S., Leverage across Firms, Banks, and Countries, "Journal of International Economics", 88(2), pp. 284-298, 2012.

Kashyap, A. K., Rajan, R., Stein, J. C., Banks as Liquidity Providers: An Explanation for the Coexistence of Lending and Deposit-Taking, "Journal of Finance", 57(1), pp. 33-73, 2002.

Kwan, S., Eisenbeis, R. A., Bank Risk, Capitalization, and Operating Effciency, "Journal of Financial Services Research", 12(2), pp. 117-131, 1997. 
Litan, R., Evaluating and Controlling the Risk of Financial Product Deregulation, Yale Journal of Regulation (Fall), 3, pp. 1-52, 1985.

Lo, A. W., The Feasibility of Systemic Risk Measurement: Written Testimony for the House Financial Services Committee Hearing on Systemic Risk Regulation. The Financial Services Committee of the US House of ... (1-11), 2009.

Lozano-Vivas, A., Pasiouras, F., The Impact of Non-traditional Activities on the Estimation of Bank Efficiency: International Evidence, "Journal of Banking and Finance", 34(7), pp. 1436-1449, 2010.

McCarthy, N., Poole, K., T., Rosenthal, H., Political Fortunes: On Finance and its Regulation, Deadalus, 4, 2010.

McGuire, P., Von Peter, G., The US Dollar Shortage in Global Banking and the International Policy Response, Working Paper No 291, Bank for International Settlement, Basel 2009.

Popov, A., Udell, G. F., Cross-Border Banking and the International Transmission of Financial Distress during the Crisis of 2007-2008, "Journal of International Economics", 87(1), pp. 147-161, 2012.

Rajan, R. G., Has Finance Made the World Riskier? "European Financial Management", 12(4), p. 499, 2006.

Rogers, K. E., Nontraditional Activities and the Efficiency of US Commercial Banks, "Journal of Banking \& Finance", 22(4), pp. 467-482, 1998.

Rossi, S. P. S., Schwaiger, M. S., Winkler, G., How Loan Portfolio Diversification Affects Risk, Efficiency and Capitalization: A Managerial Behavior Model for Austrian Banks, "Journal of Banking and Finance", 33(12), pp. 2218-2226, 2009.

Saunders, A., Walter, I., Universal Banking in the United States: What Could We Gain? What Could We Lose? Oxford University Press, New York 1994.

Saunders, A., Walter, I., Financial Architecture, Systemic Risk, and Universal Banking, "Financial Markets and Portfolio Management", 26(1), pp. 39-59, 2012.

Schmidt, R. H., Tyrell, M., What Constitutes a Financial System in General and the German Financial System in Particular? [in:] Krahnen, P. J., and Schmidt, H. R. (eds.): The German Financial System, pp. 19-67. Oxford University Press, Oxford 2004.

Shleifer, A., Vishny, R. W., Unstable Banking, "Journal of Financial Economics", 97(3), pp. 306-318, 2010.

Song, F., Thakor, A. V., Relationship Banking, Fragility, and the Asset-liability Matching Problem, "Review of Financial Studies", 20(5), pp. 2129-2177, 2007.

Stiroh, K. J., Diversification in Banking: Is Noninterest Income the Answer? "Journal of Money, Credit, and Banking", 36(5), pp. 853-882, 2004.

Stiroh, K. J., Rumble, A., The Dark Side of Diversification: The Case of US Financial Holding Companies, "Journal of Banking and Finance", 30(8), pp. 2131-2161, 2006.

Uzun, H., Webb, E., Securitization and Risk: Empirical Evidence on US Banks, "Journal of Risk Finance", 8(1), pp. 11-23, 2007.

Wagner, W., The Liquidity of Bank Assets and Banking Stability, "Journal of Banking and Finance", 31(1), pp. 121-39, 2007.

Wall, L. D., Has Bank Holding Companies' Diversification Affected Their Risk of Failure? "Journal of Economics and Business", 39(4), pp. 313-326, 1987. 
Wheelock, D. C., Wilson, P. W., Do Large Banks Have Lower Costs? New Estimates of Returns to Scale for U.S. Banks, "Journal of Money, Credit and Banking", 44(1), pp. 171199, 2012.

Wu, D., Yang, J., Hong, H., Securitization and Banks' Equity Risk, "Journal of Financial Services Research", 39(3), pp. 95-117, 2011.

Received: May 2014, revised: November 2015

Acknowledgement: The project has been funded from National Science Center based on the decision: DEC-2013/11/D/HS4/03747.

The author is very grateful to the participants of the International Risk Management Conference in Warsaw in 2014 and the World Finance Conference and Banking Symposium in Singapore in 2014 for their valuable comments. 